\title{
Diversity and Drug Resistance of Filamentous Fungi Isolated from the Fresh Raspberries
}

\author{
Ewelina Farian ${ }^{1} \cdot$ Angelina Wójcik-Fatla $^{1}$ (1)
}

Received: 1 June 2021/Accepted: 30 July 2021/Published online: 15 August 2021

(C) The Author(s) 2021

\begin{abstract}
Fungi are one of the most widely distributed microorganisms in the environment, including food such as fruits, vegetables and other crops, posing a potential threat to food safety and human health. The aim of this study was to determine the diversity, intensity and drug resistance of potentially pathogenic filamentous fungi isolated from the fresh raspberries (Rubus idaeus L.). A total of 50 strains belonging to genera Fusarium, Cladosporium, Alternaria, Penicillium, Mucor, Rhizopus, Aspergillus and Acremonium were tested for drug resistance against 11 antifungals by disc diffusion and gradient strips methods. The average mycological contamination in the examined samples of raspberries amounted to $4.34 \mathrm{log} \mathrm{CFU} / \mathrm{g}$. The Cladosporium was isolated from all tested samples, followed by Alternaria and Fusarium with a frequency of $61 \%$ and $34 \%$, respectively. The highest level of drug resistance was observed for Acremonium genera and Fusarium strains recorded a wide variation in drug resistance as revealed by susceptibility with amphotericin B and voriconzole with MICs ranged from $0.5-4 \mu \mathrm{g} / \mathrm{ml}$ and posaconazole with MICs ranging from 3-8 $\mu \mathrm{g} / \mathrm{ml}$. All fungal strains showed $100 \%$ resistance to caspofungin, fluconazole and flucytosine with both the methods, and $100 \%$ resistance to micafungin and anidulafungin in the gradient strip method.
\end{abstract}

Keywords Filamentous fungi · Drug resistance $\cdot$ Food safety $\cdot$ Raspberries

Angelina Wójcik-Fatla

afatla@poczta.onet.pl; fatla.angelina@imw.lublin.pl

Ewelina Farian

farina.ewelina@imw.lublin.pl

1 Department of Health Biohazards and Parasitology, Institute of Rural Health, Jaczewskiego 2, 20-090 Lublin, Poland
Fresh fruit play a pivotal role in human nutrition as an essential component of a healthy and balanced diet, mainly as a rich source of vitamins, minerals and biologically active compounds. Despite all these benefits, the fruit microbiome also includes potential pathogens, such as viruses, bacteria and fungi, which may pose risk for humans health by decreasing the nutritive value and/or by producing injurious toxic metabolites [1]. In particular, soft fruits are sensitive to microbial contamination, involving both the fruits surface and tissues [2]. Filamentous fungi belonging to genera Alternaria, Cladosporium, Penicillium, Fusarium and Aspergillus are mainly responsible for the spoilage of fresh fruits $[3,4]$. Infections acquired from exposure to food have been confirmed in case of Mucor, Fusarium and Rhizopus, occurred mostly among immunocompromised patients [5]. Fungi such as Aspergillus or Penicillium transmitted mainly by respiratory route, contribute to allergy, opportunistic infections or toxicosis [3, 6]. Cases of phytofungal infections, caused by Alternaria, Cladosporium and by some oomycete pathogens, have been also reported [7]. According to Antimicrobial Resistance Global Report on Surveillance, the harmful health effects of fungal infections are related with microbial resistance [8].

Antifungal resistance often appears as a result of using fungicides in agricultural ecosystems and developed as an inherited trait through natural selection process of fungi [9]. Fungal contamination of raw or minimally processed food may hold the risk for transfer of antifungal resistance to humans, similar to antibacterial resistance [10]. Current antifungal therapies are based on four groups of drugs: azoles, echinocandins, polyenes and pyrimidine analogs, however, azoles, echinocandins and polyenes are mainly applied in treatment of infections caused by filamentous fungi $[11,12]$. 
The rapidly increasing level of drug resistance of microorganisms in the natural environment is a challenge for clinicians in terms of effective treatment of infections caused by filamentous fungi. Considering the significant role of fungal contaminants in food, both from the economic and public health point of view, the aim of the study was to determine the diversity, intensity and drug resistance of filamentous fungi isolated from the fresh raspberries.

A total of 41 samples of raspberries were collected randomly from croplands and home gardens during the summer and autumn periods in 2019-2020. The samples were analysed immediately after and collection and delivery to the laboratory. The comminuted fruits samples of $10 \mathrm{~g}$ each were suspended in $90 \mathrm{ml}$ of Ringer's solution (Merck KGaA, Germany) and homogenized for 4 min with using the Bag Mixer $400 \mathrm{SW}$ (Interscience, France). To determine the fungal population density, the plate dilution method on Malt Agar (Difco, USA) with the addition of chloramphenicol was used. Each inoculated dish was incubated at $30^{\circ} \mathrm{C}$ for $72 \mathrm{~h}$, then at room temperature (during the day and night at $22{ }^{\circ} \mathrm{C}$ in a laboratory room equipped with air conditioning) for further $72 \mathrm{~h}$. Identification of filamentous fungi was based on macroscopic and microscopic methods with the use of keys and mycological atlases.

Susceptibility to antifungal drugs was determined by disc diffusion and gradient strip methods. The fungal inoculum suspensions comprising of mycelial bits and spores were prepared from 7-day old cultures grown on Malt Agar and the optical density was adjusted to a 0.5 McFarland standard. The antifungal agent discs (BioMaxima, Poland) used were: ketoconazole (10 $\mu \mathrm{g})$, amphotericin B $(20 \mu \mathrm{g})$, itraconazole $(50 \mu \mathrm{g})$, caspofungin $(5 \mu \mathrm{g})$, fluconazole $(25 \mu \mathrm{g})$, posaconazole $(5 \mu \mathrm{g})$, voriconazole
$(1 \mu \mathrm{g})$, flucytosine $(1 \mu \mathrm{g})$ and nystatin (100 IU). The discs were placed on Malt Agar medium, and incubated at $30{ }^{\circ} \mathrm{C}$ for $72 \mathrm{~h}$. The diameter of the inhibition zones was measured in millimeter (Fig. 1a). In gradient strips method, the minimum inhibitory concentration (MIC) was determined by the MIC Test Strip (Liofilchem, Italy): ketoconazole, amphotericin B, itraconazole, caspofungin, posaconazole, voriconazole, micafungin, anidulafungin, flucytosine $(0,002-32 \mu \mathrm{g} / \mathrm{ml})$ and fluconazole $(0,016-256 \mu \mathrm{g} / \mathrm{ml})$.The strips were placed on RPMI medium (BioMaxima, Poland) and incubated at $30{ }^{\circ} \mathrm{C}$ for $72 \mathrm{~h}$. MIC was read directly from the scale in terms of $\mu \mathrm{g} / \mathrm{ml}$, at the point where the edge of the inhibition ellipse intersects with the strip (Fig. 1b).

The average mycological contamination in the examined samples amounted to the value of $4.34 \mathrm{log} \mathrm{CFU} / \mathrm{g}$ (Table 1). The obtained median fungal concentration was similar to the results obtained by other researchers, with the values ranging from $4 \log \mathrm{CFU} / \mathrm{g}$ to $6 \mathrm{log} \mathrm{CFU} / \mathrm{g}$ [1]. Cladosporium could occur on raspberries at the early stage of produce storage, as well as during the storage, transport or sale stage [2]. Within this genus, the greatest number of the species was isolated from soil or plants. However, several species could affect animals and humans, including species mainly responsible for allergic rhinitis [13], such as C. sphaerospermum and C. cladosporioides isolated from raspberry fruits in this study. Alternaria and Fusarium genera were isolated from the fruits with prevalence at the level of $61 \%$ and $34.1 \%$, respectively. Tournas and Katsoudas [14] confirmed the presence of Alternaria in $46 \%$ of tested blueberries and Fusarium in $25 \%$ of probes isolated from raspberries. The pathogenic influence of Fusarium on human health has been proved with reference to eye infections, mostly occurring in tropical and subtropical climate; however, infections have also been reported in the
Fig. 1 Measurement of the zone of inhibition the growth of fungi of the genus Cladosporium in the disc diffusion method (a) and the gradient stripes method (b)

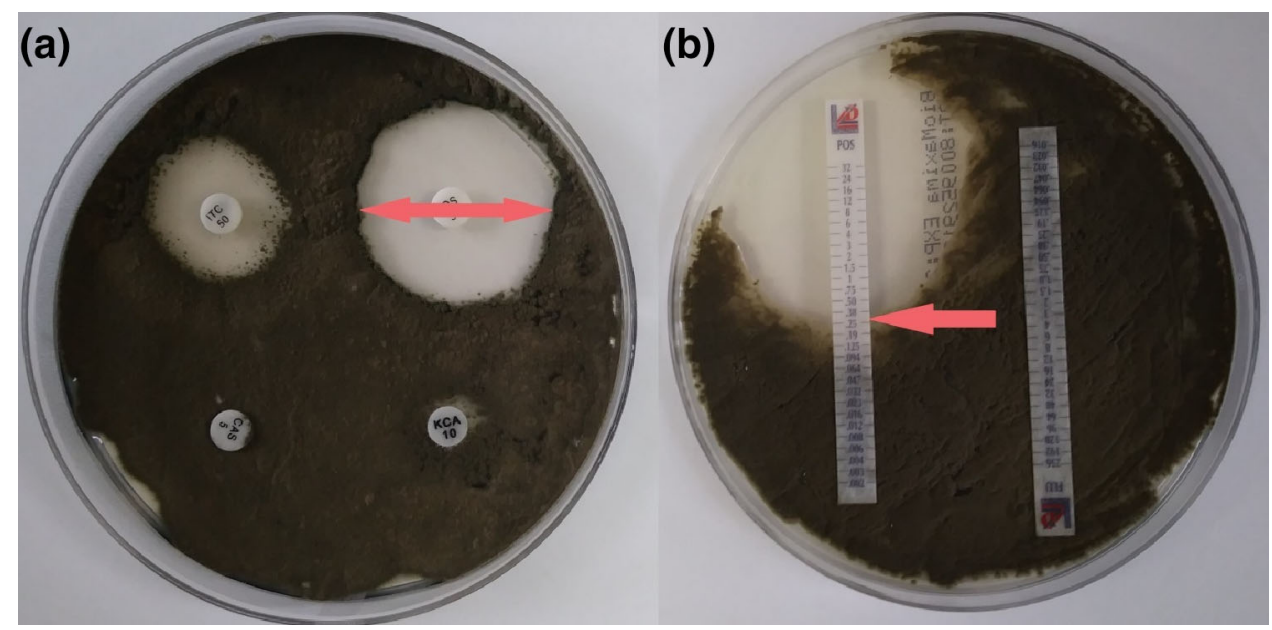


Table 1 Qualitative and quantitative mycological composition of raspberries

\begin{tabular}{|c|c|c|c|c|}
\hline Genus of filamentous fungi (species) & $\begin{array}{l}\text { No. of } \\
\text { contaminated } \\
\text { samples }(\%)\end{array}$ & $\begin{array}{l}\text { Fungal concentration } \\
\text { range }[\log \mathrm{CFU} / \mathrm{g}]\end{array}$ & $\begin{array}{l}\text { Mean + standard } \\
\text { deviation }[\log \mathrm{CFU} / \mathrm{g}]\end{array}$ & $\begin{array}{l}\text { Median } \\
{[\log } \\
\text { CFU/g] }\end{array}$ \\
\hline Cladosporium (C. cladosporioides, C. sphaerospermum) & $41(100 \%)$ & $1.74-4.88$ & $3.58( \pm 0.71)$ & 3.68 \\
\hline Alternaria (A. tenuissima, A. arborescens, A. infectoria) & $25(61 \%)$ & $0.02-1.16$ & $0.35( \pm 0.26)$ & 0.25 \\
\hline Fusarium (F. poae, F. culmorum, F. verticillioides, $F$. oxysporum) & $14(34.1 \%)$ & $0.04-0.56$ & $0.27( \pm 0.16)$ & 0.26 \\
\hline Rhizopus (R. oryzae) & $10(24.4 \%)$ & $0.04-0.35$ & $0.14( \pm 0.1)$ & 0.1 \\
\hline Penicillium ( $P$. allii, $P$. expansum) & $6(14.6 \%)$ & $0.02-0.63$ & $0.26( \pm 0.23)$ & 0.21 \\
\hline Mucor (M. racemosus) & $6(14.6 \%)$ & $0.02-0.23$ & $0.13( \pm 0.07)$ & 0.13 \\
\hline Aspergillus (A. parasiticus, A. fumigatus, A. carbonarius) & $3(7.3 \%)$ & $0.02-0.28$ & $0.15( \pm 0.13)$ & 0.16 \\
\hline Aureobasidium & $4(9.8 \%)$ & $0.15-0.34$ & $0.27( \pm 0.09)$ & 0.29 \\
\hline Microsporum & $2(4.9 \%)$ & $0.03-0.04$ & $0.04( \pm 0)$ & 0.04 \\
\hline Trichoderma & $1(2.4 \%)$ & 0.49 & 0.49 & 0.49 \\
\hline Acremonium & $1(2.4 \%)$ & 0.23 & 0.23 & 0.23 \\
\hline Humicola & $1(2.4 \%)$ & 0.1 & 0.1 & 0.1 \\
\hline Non-sporulating fungi & $34(82.9 \%)$ & $0.02-1.32$ & $0.37( \pm 0.28)$ & 0.26 \\
\hline Total samples & $41(100 \%)$ & $3.48-5.13$ & $4.34( \pm 0.39)$ & 4.36 \\
\hline
\end{tabular}

Table 2 Assessment of sensitivity to selected antifungal drugs among filamentous fungi isolated from raspberries using the disc diffusion method

\begin{tabular}{|c|c|c|c|c|c|c|c|c|c|}
\hline \multirow{2}{*}{$\begin{array}{l}\text { Genera of fungi } \\
\text { (number of strains) }\end{array}$} & \multicolumn{9}{|c|}{ Zone of inhibition [mm] Range (geometric mean; number of strains showing growth inhibition) } \\
\hline & $\mathrm{KCA}$ & AMB & ITC & CAS & FLU & POS & VOR & AFY & NY \\
\hline $\begin{array}{l}\text { Fusarium } \\
(\mathrm{n}=10)\end{array}$ & $\begin{array}{l}0-16 \\
(11.7 ; \mathrm{n}=3)\end{array}$ & $\begin{array}{l}0-11 \\
(11 ; n=1)\end{array}$ & $\begin{array}{l}0-15 \\
(12.2 ; \mathrm{n}=2)\end{array}$ & rs* & rs & $\begin{array}{l}0-29 \\
(23.3 ; n=6)\end{array}$ & $\begin{array}{l}0-20 \\
(17.3 ; \mathrm{n}=5)\end{array}$ & rs & $\begin{array}{l}0-25 \\
(13.5 ; \mathrm{n}=8)\end{array}$ \\
\hline $\begin{array}{l}\text { Cladosporium } \\
(\mathrm{n}=10)\end{array}$ & $\begin{array}{l}0-21 \\
(13.5 ; n=6)\end{array}$ & rs & $\begin{array}{l}15-30 \\
(22.0 ; \mathrm{n}=10)\end{array}$ & rs & rs & $\begin{array}{l}29-41 \\
(32.9 ; \mathrm{n}=10)\end{array}$ & rs & rs & $\begin{array}{l}17-23 \\
(19.6 ; n=10)\end{array}$ \\
\hline $\begin{array}{l}\text { Alternaria } \\
(\mathrm{n}=10)\end{array}$ & $\begin{array}{l}0-10 \\
(10.0 ; n=6)\end{array}$ & rs & $\begin{array}{l}17-25 \\
(18.5 ; \mathrm{n}=10)\end{array}$ & rs & rs & $\begin{array}{l}28-32 \\
(29.4 ; \mathrm{n}=10)\end{array}$ & rs & rs & $\begin{array}{l}19-21 \\
(20.0 ; \mathrm{n}=10)\end{array}$ \\
\hline $\begin{array}{l}\text { Penicillium } \\
(\mathrm{n}=10)\end{array}$ & $\begin{array}{l}10-23 \\
(16.4 ; \mathrm{n}=7)\end{array}$ & rs & $\begin{array}{l}23-35 \\
(26.5 ; \mathrm{n}=7)\end{array}$ & rs & rs & $\begin{array}{l}12-45 \\
(30.4 ; \mathrm{n}=10)\end{array}$ & $\begin{array}{l}10-18 \\
(13.2 ; n=6)\end{array}$ & rs & $\begin{array}{l}13-28 \\
(17.9 ; \mathrm{n}=10)\end{array}$ \\
\hline $\begin{array}{l}\text { Mucor } \\
(\mathrm{n}=3)\end{array}$ & rs & $\begin{array}{l}0-8 \\
(8 ; n=1)\end{array}$ & $\begin{array}{l}0-13 \\
(13 ; \mathrm{n}=1)\end{array}$ & rs & rs & $\begin{array}{l}10-20 \\
(15.0 ; \mathrm{n}=3)\end{array}$ & rs & rs & $\begin{array}{l}20-21 \\
(20.7 ; \mathrm{n}=3)\end{array}$ \\
\hline $\begin{array}{l}\text { Rhizopus } \\
(\mathrm{n}=3)\end{array}$ & $\begin{array}{l}12 \\
(12 ; n=3)\end{array}$ & $\begin{array}{l}0-8 \\
(8 ; n=1)\end{array}$ & $\begin{array}{l}18-20 \\
(19.3 ; \mathrm{n}=3)\end{array}$ & rs & rs & $\begin{array}{l}25 \\
(25 ; \mathrm{n}=3)\end{array}$ & rs & rs & $\begin{array}{l}23 \\
(23 ; n=3)\end{array}$ \\
\hline $\begin{array}{l}\text { Aspergillus } \\
(\mathrm{n}=3)\end{array}$ & $\begin{array}{l}0-20 \\
(20 ; n=3)\end{array}$ & rs & $\begin{array}{l}22-25 \\
(23.0 ; \mathrm{n}=3)\end{array}$ & rs & rs & $\begin{array}{l}33-35 \\
(34.3 ; n=3)\end{array}$ & $\begin{array}{l}10-15 \\
(12.2 ; \mathrm{n}=3)\end{array}$ & rs & $\begin{array}{l}17-20 \\
(18.3 ; \mathrm{n}=3)\end{array}$ \\
\hline $\begin{array}{l}\text { Acremonium } \\
(\mathrm{n}=1)\end{array}$ & rs & rs & rs & rs & rs & rs & rs & rs & rs \\
\hline
\end{tabular}

*rs-fungi resistant to antifungal drugs (no zone of inhibition of growth)

Anti-fungal discs: ketoconazole (KCA), amphotericin B (AMB), itraconazole (ITC), caspofungin (CAS), fluconazole (FLU), posaconazole (POS), voriconazole (VOR), flucytosine (AFY) and nystatin (NY)

Netherlands [15]. The case of human ocular infection with Alternaria infectoria has also been confirmed after eyeperforating trauma caused by lemon tree branch [7].
Among others potentially pathogenic fungi with the ability to produce mycotoxins, Rhizopus (24.4\%), Mucor (14.6\%), Penicillium (14.6\%) and Aspergillus (7.3\%) were isolated from the tested raspberries. The prevalence of 
Table 3 Assessment of sensitivity to selected antifungal drugs among filamentous fungi isolated from raspberries using the gradient strip method

\begin{tabular}{|c|c|c|c|c|c|c|c|c|c|c|}
\hline \multirow[t]{2}{*}{$\begin{array}{l}\text { Genera of fungi } \\
\text { (number of strains) }\end{array}$} & \multicolumn{10}{|c|}{$\begin{array}{l}\text { MIC value }[\mu \mathrm{g} / \mathrm{ml}] \\
\text { Range (geometric mean; number of strains showing growth inhibition) }\end{array}$} \\
\hline & $\mathrm{KCA}$ & AMB & ITC & CAS & FLU & POS & VOR & MI & ANI & AFY \\
\hline $\begin{array}{l}\text { Fusarium } \\
(\mathrm{n}=10)\end{array}$ & $\mathrm{Rs}^{*}$ & $\begin{array}{l}0.5-4 \\
(2 ; n=3)\end{array}$ & rs & rs & rs & $\begin{array}{l}3-8 \\
(5.1 ; \mathrm{n}=5)\end{array}$ & $\begin{array}{l}0.50-4 \\
(1.3 ; \mathrm{n}=7)\end{array}$ & rs & rs & rs \\
\hline $\begin{array}{l}\text { Cladosporium } \\
(\mathrm{n}=10)\end{array}$ & $\begin{array}{l}0.25-1.50 \\
(0.9 ; \mathrm{n}=10)\end{array}$ & $\begin{array}{l}1-3 \\
(1.8 ; \mathrm{n}=10)\end{array}$ & $\begin{array}{l}0.25-3 \\
(1.0 ; \mathrm{n}=10)\end{array}$ & rs & rs & $\begin{array}{l}0.094-0.50 \\
(0.3 ; \mathrm{n}=10)\end{array}$ & $\begin{array}{l}0.25-3 \\
(1.3 ; \mathrm{n}=10)\end{array}$ & rs & rs & rs \\
\hline $\begin{array}{l}\text { Alternaria } \\
(\mathrm{n}=10)\end{array}$ & $\begin{array}{l}2-4 \\
(3.2 ; n=3)\end{array}$ & $\begin{array}{l}0.50-2 \\
(1.2 ; \mathrm{n}=10)\end{array}$ & $\begin{array}{l}4-12 \\
(7.6 ; n=9)\end{array}$ & rs & rs & $\begin{array}{l}0.75-2 \\
(1.3 ; n=10)\end{array}$ & $\begin{array}{l}1.50-12 \\
(4.6 ; n=6)\end{array}$ & rs & rs & rs \\
\hline $\begin{array}{l}\text { Penicillium } \\
(\mathrm{n}=10)\end{array}$ & $\begin{array}{l}0.19-8 \\
(2.1 ; n=7)\end{array}$ & $\begin{array}{l}0.50-4 \\
(1.4 ; \mathrm{n}=5)\end{array}$ & $\begin{array}{l}1-24 \\
(3.9 ; n=7)\end{array}$ & rs & rs & $\begin{array}{l}0.125-2 \\
(0.6 ; \mathrm{n}=7)\end{array}$ & $\begin{array}{l}0.094-3 \\
(0.7 ; \mathrm{n}=6)\end{array}$ & rs & rs & rs \\
\hline $\begin{array}{l}\text { Mucor } \\
(\mathrm{n}=3)\end{array}$ & rs & $\begin{array}{l}1.5-4 \\
(2.3 ; n=3)\end{array}$ & rs & rs & rs & $\begin{array}{l}6-8 \\
(6.9 ; n=2)\end{array}$ & rs & rs & rs & rs \\
\hline $\begin{array}{l}\text { Rhizopus } \\
(\mathrm{n}=3)\end{array}$ & $\begin{array}{l}6-8 \\
(6.6 ; n=3)\end{array}$ & $\begin{array}{l}0.094-0.19 \\
(0.15 ; \mathrm{n}=3)\end{array}$ & $\begin{array}{l}16 \\
(16 ; n=3)\end{array}$ & rs & rs & $\begin{array}{l}4-6 \\
(5.8 ; n=3)\end{array}$ & rs & rs & rs & rs \\
\hline $\begin{array}{l}\text { Aspergillus } \\
(\mathrm{n}=3)\end{array}$ & $\begin{array}{l}3-12 \\
(6 ; n=2)\end{array}$ & $\begin{array}{l}0.75-3 \\
(1.3 ; \mathrm{n}=3)\end{array}$ & $\begin{array}{l}2-4 \\
(2.9 ; n=3)\end{array}$ & rs & rs & $\begin{array}{l}0.38-0.50 \\
(0.4 ; \mathrm{n}=2)\end{array}$ & $\begin{array}{l}0.38-2 \\
(0.7 ; n=3)\end{array}$ & rs & rs & rs \\
\hline $\begin{array}{l}\text { Acremonium } \\
(\mathrm{n}=1)\end{array}$ & rs & rs & rs & rs & rs & rs & rs & rs & rs & rs \\
\hline
\end{tabular}

*r-fungi resistant to antifungal drugs (no zone of inhibition of growth)

Gradient strips: ketoconazole (KCA), amphotericin B (AMB), itraconazole (ITC), caspofungin (CAS), fluconazole (FLU), posaconazole (POS), voriconazole (VOR), micafungin (MI), anidulafungin (ANI) and flucytosine (AFY)

these genus has been also confirmed on blueberries, strawberries and grapes [14]. The large group of mycological contamination were non-sporulating fungi identified in almost $83 \%$ of examined samples, mainly responsible for respiratory tract infections [16].

All fungal strains isolated from the raspberries showed $100 \%$ resistance to caspofungin, fluconazole and flucytosine in both methods and $100 \%$ resistance to micafungin, flucytosine and anidulafungin in the gradient strips method (Table 2 and 3). The highest drug resistance was observed in the case of Acremonium spp. (on 10 out of 11 tested antibiotics with the exception of the nystatin). In contrast to the strains isolated from environmental sources, the effectiveness of selected antibiotics, such as posaconazole and voriconazole against Acremonium species isolated from clinical samples, has been proved by in vitro studies [17]. Among the genus Fusarium, the greatest variation occurred in drug resistance among individual strains isolated from raspberries. As indicated by Sav et al. [11], the variation could be related with the ability of particular Fusarium strains to form biofilms, which may significantly increase the resistance. Antifungal susceptibility among clinical samples has been confirmed to amphotericin B, with MICs mostly ranging from $0.5-4 \mu \mathrm{g} / \mathrm{ml}$ [18], at the same level as in the present study. Al-Hatmi et al. [18] indicated that two of the most active drugs against Fusarium species were voriconazole and posaconazole, which is confirmed in this study (Table 3).

Particularly noteworthy are the fungi belonging to the Aspergillus, which can cause life-threatening infections, especially in people with the weakened immune systems [9]. Aspergillus strains isolated from raspberries showed complete resistance to caspofungin, fluconazole, micafungin, anidulafungin and flucytosine. The rapid development of multi-drug resistance noticed in the case of $A$. fumigatus was the reason for placement of this species on the watch list within the report on antimicrobial resistance of the Centers for Disease Control and Prevention in the USA in 2019 [6].

Among different classes of drugs belonged to echinocandins, azoles, polyenes and pyrimidine analogues used in this study, the wide tolerance spectrum of tested fungal strains has been confirmed in at least two of them. According to many researches, the high antifungal resistance is related with the great number of pesticides used nowadays used in agriculture [9]. As a consequence, 
prolonged fungicide exposure may result in the occurrence of many more multi-drug-resistant fungal strains in fruits, vegetables and other crops, affecting both human health and food safety. Contamination of food with drug resistant fungi (especially multi-drug resistant) carries a risk of environmental resistance transmission to humans, reducing the treatment efficacy of potential human infections [8].

Taking into consideration that the most of filamentous fungi isolated from plants could be opportunistic pathogens to humans and the significant increase in the availability and widespread use of drugs, this work may be useful for further clinical research. The obtained results may also provide useful information to develop novel methods against fungal contamination for fruit at the early stage of production, during storage, transport and sale stage, as well as to determine appropriate standards and regulations for improving food safety, thereby limiting the risk of exposure to humans' health.

Funding The study was funded by Institute of Rural Health within a subsidy from the Ministry of Science and Higher Education in Warsaw, Poland (Project No. 20003)

\section{Declarations}

Conflict of interest The authors declare that there is no conflict of interest.

Open Access This article is licensed under a Creative Commons Attribution 4.0 International License, which permits use, sharing, adaptation, distribution and reproduction in any medium or format, as long as you give appropriate credit to the original author(s) and the source, provide a link to the Creative Commons licence, and indicate if changes were made. The images or other third party material in this article are included in the article's Creative Commons licence, unless indicated otherwise in a credit line to the material. If material is not included in the article's Creative Commons licence and your intended use is not permitted by statutory regulation or exceeds the permitted use, you will need to obtain permission directly from the copyright holder. To view a copy of this licence, visit http://creativecommons. org/licenses/by/4.0/.

\section{References}

1. Eliasa MI, Madureiraa J, Santosa PMP, Carolinob MM, Margaçaa FMA, Cabo Verdea S (2020) Preservation treatment of fresh raspberries by e-beam irradiation. Innov Food Sci Emerg Technol 66:102487. https://doi.org/10.1016/j.ifset.2020.102487

2. Swett CL, Hamby KA, Hellman EM, Carignan C, Bourret TB, Koivunen EE (2019) Characterizing members of the Cladosporium cladosporioides species complex as fruit rot pathogens of red raspberries in the mid-Atlantic and co-occurrence with Drosophila suzukii (spotted wing drosophila). Phytoparasitica 47:415-428. https://doi.org/10.1007/s12600-019-00734-1
3. Lorenzini M, Zapparoli G (2015) Occurrence and infection of Cladosporium, Fusarium, Epicoccum and Aureobasidium in withered rotten grapes during post-harvest dehydration. Antonie Van Leeuwenhoek 108(5):1171-1180. https://doi.org/10.1007/ s10482-015-0570-8

4. López-Anchondo AN, López-de la Cruz D, Gutiérrez-Reyes E, Castañeda-Ramírez JC, De la Fuente-Salcido NM (2021) Antifungal activity in vitro and in vivo of mesquite extract (Prosopis glandulosa) against phytopathogenic fungi. Indian $\mathrm{J}$ Microbiol 61:85-90. https://doi.org/10.1007/s12088-020-00906-2

5. Benedict K, Chiller TM, Mody RK (2016) Invasive fungal infections acquired from contaminated food or nutritional supplements: a review of the literature. Foodborne Pathog Dis 13:343-349. https://doi.org/10.1089/fpd.2015.2108

6. Centers for Disease Control and Prevention (2019) Department of health and human services. antibiotic resistance threats in the United States. Atlanta. https://www.cdc.gov/drugresistance/pdf/ threats-report/2019-ar-threats-report-508.pdf Accessed 25 May 2021.

7. Kim JS, Yoon SJ, Park YJ, Kim SY, Ryu CM (2020) Crossing the kingdom border: human diseases caused by plant pathogens. Environ Microbiol 22:2485-2495. https://doi.org/10.1111/14622920.15028

8. Manaia CM (2017) Assessing the risk of antibiotic resistance transmission from the environment to humans: non-direct proportionality between abundance and risk. Trends Microbiol 25:173-181. https://doi.org/10.1016/j.tim.2016.11.014

9. Brauer VS, Rezende CP, Pessoni AM, De Paula RG, Rangappa KS, Nayaka SC, Gupta VK, Almeida F (2019) Antifungal agents in agriculture: friends and foes of public health. Biomolecules 9:521. https://doi.org/10.3390/biom9100521

10. Anas M, Malik A (2021) Impact of sodium alginate packaging film synthesized using Syzygium cumini seed extract on multi drug resistant Escherichia coli isolated from raw buffalo meat. Indian J Microbiol 61:137-150. https://doi.org/10.1007/s12088021-00923-9

11. Sharma C, Chowdhary A (2017) Molecular bases of antifungal resistance in filamentous fungi. Int $\mathrm{J}$ Antimicrob Agents 50:607-616. https://doi.org/10.1016/j.ijantimicag.2017.06.018

12. Sav H, Rafati H, Öz Y, Dalyan-Cilo B, Ener B, Mohammadi F, Ilkit M, van Diepeningen AD, Seyedmousavi S (2018) Biofilm formation and resistance to fungicides in clinically relevant members of the fungal genus Fusarium. J Fungi (Basel) 4:16. https://doi.org/10.3390/jof4010016

13. Sandoval-Denis M, Sutton DA, Martin-Vicente A, Cano-Lira JF, Wiederhold N, Guarro J, Gené J (2015) Cladosporium species recovered from clinical samples in the United States. J Clin Microbiol 53:2990-3000. https://doi.org/10.1128/JCM.01482-15

14. Tournas VH, Katsoudas E (2005) Mould and yeast flora in fresh berries, grapes and citrus fruits. Int J Food Microbiol 105:11-17. https://doi.org/10.1016/j.ijfoodmicro.2005.05.002

15. Oliveira Dos Santos C, Kolwijck E, van Rooij J, Stoutenbeek R, Visser N, Cheng YY, Santana NTY, Verweij PE, Eggink CA (2020) Epidemiology and clinical management of fusarium keratitis in the Netherlands, 2005-2016. Front Cell Infect Microbiol 3:133. https://doi.org/10.3389/fcimb.2020.00133

16. Singh PK, Kathuria S, Agarwal K, Gaur SN, Meis JF, Chowdhary A (2013) Clinical significance and molecular characterization of nonsporulating molds isolated from the respiratory tracts of bronchopulmonary mycosis patients with special reference to basidiomycetes. J Clin Microbiol 51:3331-3337. https://doi.org/ 10.1128/JCM.01486-13 
17. Yao L, Wang H, Wan Z, Li R, Yu J (2019) The high diversity and variable susceptibility of clinically relevant Acremonium-like species in China. Mycopathologia 184:759-773. https://doi.org/ 10.1007/s11046-019-00399-8

18. Al-Hatmi AM, van Diepeningen AD, Curfs-Breuker I, de Hoog GS, Meis JF (2015) Specific antifungal susceptibility profiles of opportunists in the Fusarium fujikuroi complex. J Antimicrob Chemother 70:1068-1071. https://doi.org/10.1093/jac/dku50

Publisher's Note Springer Nature remains neutral with regard to jurisdictional claims in published maps and institutional affiliations. 